\title{
ROLE OF LIPID PROFILE IN PATHOGENESIS OF DIABETIC RETINOPATHY
}

\author{
Jagannadha Phaneendra Dingari Sree1, Vusikala Sunanda², Imran Ahmed Siddique 3 \\ ${ }^{1}$ Assistant Professor, Department of Biochemistry, Kamineni Academy of Medical Sciences and Research Centre. \\ 2 Professor \& HOD, Department of Biochemistry, Kamineni Academy of Medical Sciences and Research Centre. \\ 3Senior Consultant, Department of Biochemistry, ESI Hospital, Sanathnagar.
}

\section{ABSTRACT}

Diabetes mellitus is a major metabolic disease associated with macrovascular and microvascular complications. Diabetic retinopathy is a highly specific vascular complication of Type 2 diabetes mellitus and is emerging as one of the causes of blindness in both developing and developed countries. Alteration in lipid levels in diabetics is hypothesized to be one of the risk factor in causation of retinopathy in DR subjects. The present study was to elucidate the role of serum lipids as a risk factor in causation of Diabetic retinopathy.

\section{MATERIALS AND METHODS}

A total number of 120 subjects aged between 40-70 yrs. participated in the study. They were divided into three groups. Gr. I Diabetics without retinopathy (40), Gr. II Diabetics with retinopathy (40), Gr. III control group age and sex matched without history of Diabetes. Serum Total cholesterol, Triglycerides, HDL cholesterol were estimated by Enzymatic methods. LDL cholesterol was calculated by Friedewald's equation.

\section{STATISTICAL ANALYSIS}

The data was analysed using SPSS software 17.0 version. $\mathrm{P}<0.05$ is considered statistically significant.

\section{RESULTS}

It was found that Serum Total Cholesterol $(p=0.004)$, TG $(p<0.001)$, LDL cholesterol $(p=0.013)$ were significantly elevated in Diabetics with retinopathy as compared to controls. Serum HDL cholesterol was significantly $(\mathrm{p}<0.001)$ decreased in Diabetics with retinopathy as compared to controls, whereas no statistically significant difference in Mean and SD of Total Cholesterol, TG'S, HDLC, LDL-C was found between Diabetics with retinopathy and Diabetics without Retinopathy.

\section{CONCLUSION}

Our study shows that increased lipid levels probably has a role in the causation and progression of Diabetic retinopathy.

\section{KEYWORDS}

Lipid Profile, Diabetes Mellitus, Diabetic Retinopathy.

HOW TO CITE THIS ARTICLE: Sree JPD, Sunanda V, Siddique IA. Role of lipid profile in pathogenesis of diabetic retinopathy. J. Evolution Med. Dent. Sci. 2016;5(14):627-629, DOI: 10.14260/jemds/2016/143

\section{INTRODUCTION}

Diabetes is a group of metabolic diseases characterized by hyperglycemia resulting from defects in insulin secretion, insulin action or both. The prevalence of diabetes for all age groups worldwide was estimated to be $2.8 \%$ in 2000 and $4.4 \%$ in 2030. In India this increase of burden of diabetes is estimated to rise from 51 million people to 87 million people in 2030.1,2 Chronic complications of Diabetes Mellitus (DM) affect many organ systems and are responsible for majority of morbidity and mortality. Chronic complications of Diabetes mellitus include Macrovascular complications like coronary artery disease, cerebrovascular disease, peripheral vascular disease. Microvascular complications include Retinopathy, Nephropathy, Neuropathy, Diabetic Retinopathy (DR) is highly specific complication of both Type I and Type II DM. ${ }^{3}$

Financial or Other, Competing Interest: None.

Submission 01-01-2016, Peer Review 29-01-2016,

Acceptance 05-02-2016, Published 16-02-2016.

Corresponding Author:

Jagannadha Phaneendra Dingari Sree,

H. No. 11-12-152, Plot No-114B, Sree Nilayam,

Road No. 3, Sri Rama Krishnapuram, Income Tax Colony,

Post: Saroornagar, R. R. Dist., Hyderabad-500102.

E-mail:dingari.jagan@gmail.com

DOI: $10.14260 /$ jemds/2016/143
Risk factors associated with DR include duration of Diabetes, Glycaemic control, Systolic blood pressure, Dyslipidemia, smoking, Microalbuminuria. Fewer studies have looked at association of serum lipids with microvascular complications. ${ }^{4}$ Moreover, the studies of association of Lipids with microvasular complications of DM show varying results. In this study, we made an attempt to look into association of various components of serum lipids and their role in pathogenesis of Diabetic Retinopathy.

\section{MATERIALS AND METHODS}

The present study was a (Case control) study conducted at Osmania Medical College/Hospital during the year 2011-2012. Ethical committee clearance was obtained before the start of study. Patients attending the OP of General Medicine Department and Retinal Clinic of Ophthalmology Department were the source population. A total no. of 120 subjects between age group 40-70 yrs. of both genders were included in the study. The Subjects were divided into three groups: Group I comprised of 40 Diabetics without Retinopathy, Group II comprised of 40 Diabetics with Retinopathy, Group III was control group which included 40 Non-Diabetic age, sex matched individuals. The classification of subjects into Diabetics was done based on American Diabetic association criteria. $^{5}$ 
The Diabetic population included Diabetics with history of diabetes at least for minimum of six years. The classification of subjects into diabetics with and without retinopathy was based on retinoscopy findings such as microaneurysms, hemorrhages and proliferative changes.

\section{BIOCHEMICAL ANALYSIS}

Informed consent was taken from the participants prior to collection of sample. Participants were in overnight fasting status; $10 \mathrm{~mL}$ of venous blood was drawn by venipuncture and was put into three tubes, one having sodium fluoride and potassium oxalate one with EDTA and the other was a plain tube for assessing FBS, Glycated Hemoglobin (Gly. Hb), Lipid profile respectively. FBS was measured using GOD-POD method. Gly. Hb was measured using Ion Exchange Resin method. Serum Total cholesterol (TC), Triglycerides (TG), HDL Cholesterol (HDL-C) were measured by Enzymatic methods (Cholesterol oxidase-PAP for TC, GPO-PAP for TG's, PEGCHOD-PAP End point assay for HDL-C respectively).6,7,8

\section{STATISTICAL ANALYSIS}

The data obtained was analysed using SPS software version 17.0. The descriptive results are expressed as Mean and SD of various parameters in different groups. $\mathrm{P}$ value $<0.05$ was taken as significant.

\section{RESULTS}

The mean age of control group was 55.2 yrs. The mean age of diabetics without retinopathy group was 53.4 yrs. and the mean age of diabetics with retinopathy was 52.3 yrs. The significance of difference of mean values of different groups and within groups is represented by $p$ values and $p<0.05$ is considered as significant. The mean values of Total cholesterol $(p=0.011)$, TG $(p=0.004)$, LDL cholesterol $(p=0.003)$ were significantly higher in diabetics without retinopathy as compared to controls (Table 1). The mean values of HDL cholesterol was significantly $(<0.001)$ lower in diabetics without retinopathy as compared to controls. The mean values of Total cholesterol (0.004), TG's $(<0.001)$, LDL cholesterol (0.013) were significantly higher in diabetics with retinopathy as compared with controls. The mean values of HDL cholesterol was significantly $(<0.001)$ lower in diabetics with retinopathy as compared with controls. The difference in mean value of Total cholesterol, TG, LDL cholesterol, HDL cholesterol in between diabetics with and without retinopathy was not statistically significant.

\begin{tabular}{|c|c|c|c|}
\hline Parameter & $\begin{array}{c}\text { Group I } \\
\text { (Diabetics } \\
\text { without } \\
\text { Retinopathy) }\end{array}$ & $\begin{array}{c}\text { Group III } \\
\text { (Controls) }\end{array}$ & $\begin{array}{c}\text { P } \\
\text { value }\end{array}$ \\
\hline FBS & $158.5 \pm 44.66$ & $88.67 \pm 15.03$ & $<0.001$ \\
\hline Gly. Hb & $8.31 \pm 2.01$ & $5.10 \pm 0.44$ & $<0.001$ \\
\hline $\begin{array}{c}\text { Total } \\
\text { Cholesterol }\end{array}$ & $179.45 \pm 48.94$ & $152.42 \pm 22.75$ & 0.011 \\
\hline Triglycerides & $166.35 \pm 74.73$ & $116.67 \pm 32.88$ & 0.004 \\
\hline $\begin{array}{c}\text { LDL } \\
\text { Cholesterol }\end{array}$ & $112.02 \pm 46.45$ & $84.00 \pm 20.16$ & 0.003 \\
\hline $\begin{array}{c}\text { HDL } \\
\text { Cholesterol }\end{array}$ & $37.02 \pm 6.88$ & $44.95 \pm 4.16$ & $<0.001$ \\
\hline $\begin{array}{c}\text { Table 1: Comparison of Mean, SD, P-value between } \\
\text { Diabetics without Retinopathy and Controls }\end{array}$ \\
\hline
\end{tabular}

\begin{tabular}{|c|c|c|c|}
\hline Parameter & $\begin{array}{c}\text { Group II } \\
\text { (Diabetics } \\
\text { with } \\
\text { Retinopathy) }\end{array}$ & $\begin{array}{c}\text { Group III } \\
\text { (Controls) }\end{array}$ & $\begin{array}{c}\text { P } \\
\text { value }\end{array}$ \\
\hline FBS & $167.97 \pm 42.68$ & $88.67 \pm 15.03$ & $<0.001$ \\
\hline Gly. Hb & $8.45 \pm 1.74$ & $5.10 \pm 0.44$ & $<0.001$ \\
\hline $\begin{array}{c}\text { Total } \\
\text { Cholesterol }\end{array}$ & $182.42 \pm 41.70$ & $152.42 \pm 22.75$ & 0.004 \\
\hline Triglycerides & $199.30 \pm 77.21$ & $116.67 \pm 32.88$ & $<0.001$ \\
\hline $\begin{array}{c}\text { LDL } \\
\text { Cholesterol }\end{array}$ & $107.89 \pm 34.81$ & $84.00 \pm 20.16$ & 0.013 \\
\hline $\begin{array}{c}\text { HDL } \\
\text { Cholesterol }\end{array}$ & $34.70 \pm 5.16$ & $44.95 \pm 4.16$ & $<0.001$ \\
\hline \multicolumn{3}{|c|}{$\begin{array}{c}\text { Table 2: Comparison of Mean, SD, P-value between } \\
\text { Diabetics with Retinopathy and Controls }\end{array}$} \\
\hline
\end{tabular}

\begin{tabular}{|c|c|c|c|}
\hline Parameter & $\begin{array}{c}\text { Group I } \\
\text { (Diabetics } \\
\text { without } \\
\text { Retinopathy) }\end{array}$ & $\begin{array}{c}\text { Group II } \\
\text { (Diabetics } \\
\text { with } \\
\text { Retinopathy) }\end{array}$ & $\begin{array}{c}\text { P } \\
\text { value }\end{array}$ \\
\hline FBS & $158.5 \pm 44.66$ & $167.97 \pm 42.68$ & 0.516 \\
\hline Gly. Hb & $8.31 \pm 2.01$ & $8.45 \pm 1.74$ & 0.917 \\
\hline $\begin{array}{c}\text { Total } \\
\text { Cholesterol }\end{array}$ & $179.45 \pm 48.94$ & $182.42 \pm 41.70$ & 0.945 \\
\hline Triglycerides & $166.35 \pm 74.73$ & $199.30 \pm 77.21$ & 0.080 \\
\hline $\begin{array}{c}\text { LDL } \\
\text { Cholesterol }\end{array}$ & $112.02 \pm 46.45$ & $107.89 \pm 34.81$ & 0.873 \\
\hline $\begin{array}{c}\text { HDL } \\
\text { Cholesterol }\end{array}$ & $37.02 \pm 6.88$ & $34.70 \pm 5.16$ & 0.174 \\
\hline \multicolumn{4}{|c|}{$\begin{array}{c}\text { Table 3: Comparison of Mean and SD, P-value } \\
\text { between Diabetics with and without Retinopathy }\end{array}$} \\
\hline
\end{tabular}

\section{DISCUSSION}

Various studies have shown that diabetes is associated with dyslipidemia in the form of hypercholesterolemia and hypertriglyceridemia. ${ }^{9,10,11,12}$ Studies of association of Lipid with microvascular complications of DM like retinopathy have shown varying results. The Wisconsin epidemiologic study of Diabetic Retinopathy, Klein et al. reported an association of Serum Cholesterol with severity of hard exudates in macula. ${ }^{13}$ Van Leiden et al, showed an association between Triglyceride levels and Diabetic Retinopathy in subjects with type 2 diabetes. ${ }^{14}$ Haddad and Saad found that Plasma Total Cholesterol and Triglycerides were risk factors for Diabetic Retinopathy. ${ }^{15}$ Reema et al. (2006) showed association of TG with DR and LDL with diabetic macular oedema in Chennai Urban Rural Epidemiology Study Eye study. ${ }^{16}$ The Diabetes Control and Complications Trial. ${ }^{17}$ found that the severity of Retinopathy was associated with increase in Triglycerides and inversely associated with HDL cholesterol.

However, (Larson et al. and Hove et al. found no association between Triglycerides, Total Cholesterol, HDL Cholesterol with Diabetic Retinopathy. ${ }^{18,19}$ Ozer et al. found no correlation between Serum Lipids and Macular Edema in Diabetic patients. ${ }^{20}$ In the present study, it was found that Total cholesterol, TG, LDL-C were significantly higher in Diabetics without Retinopathy and Diabetics with Retinopathy as compared to control group.

Lack of Insulin causes increased release of FFA from adipose tissue. These FFA are used as substrates for Triglyceride synthesis by the Liver. Decreased clearance of TG 
due to low lipoprotein lipase activity in the absence of insulin. ${ }^{21,22}$ The above mechanisms probably have caused an increase in TG's in both the patient groups.

It is hypothesized that the increased TG levels might lead to increased blood viscosity and altered fibrinolytic activity, which may lead to formation of hard exudates. ${ }^{23}$ Even the raised TG may get incorporated into cell membrane altering its fluidity and permeability leading to hemorrhage and edema.

In the present study, there was an increase in means of Total Cholesterol and Triglycerides in Diabetics with Retinopathy as compared to Diabetics without Retinopathy. This might explain the role of these in Pathogenesis of Diabetic Retinopathy, but the difference was not statistically significant. This might be due to the limited number of sample size studied. A large population study needs to be done to clearly establish the role of Lipid profile in causation of Diabetic Retinopathy.

\section{CONCLUSION}

Our study shows that alteration in Lipid profile has a role as a risk factor in causation and pathogenesis of Diabetic Retinopathy.

\section{REFERENCES}

1. Wild S, Roglic G, Green A, et al. Global prevalence of diabetes: estimates for the year 2000 and projections for 2030. Diabetes care 2004;27:1047-1053.

2. Ramachandran A, Snehalatha C, Viswanathan V. Burden of type 2 diabetes and its complications - The Indian Scenario. Current Science 2002;83:1471-1476.

3. Rand LI, Krolewski AS, Aiello LM, et al. Multiple factors in the prediction of risk of proliferative diabetic retinopathy. N Engl J Med 1985;313:1433-1438.

4. Rema M, Srivastava BK, Anitha B, et al. Association of serum lipids with diabetic retinopathy in Urban South Indians - the Chennai Urban Rural Epidemiology Study (CURES) Eye study-2, Diabet Med 2006 Sept;23(9):102936.

5. American Diabetes Association. Diagnosis and Classification of Diabetes Mellitus. Diabetes Care 2011; Vol:34, Suppl 1, s12-s13.

6. Herbert K. Lipids in clinical chemistry, theory analysis and correlation. Kaplan LA and Pesce AJ, eds. CV Moby, Toronto, 1984; p- 1182-1230.

7. Kaplan A, Lavernel LS. Lipid metabolism. In clinical chemistry; Interpretation and techniques $2^{\text {nd }}$ ed., Lea and Febiger, Philadelphia, 1983, Pg. 333-336.
8. Nader R, Paul B, John A. Lipids, lipoproteins and apolipoproteins, in Teitz textbook of clinical chemistry, $3^{\text {rd }}$ ed. Burtis, Philadelphia, 1994; Pg. 809-852.

9. American Diabetic Association: Detection and management of lipid disorders in diabetes. Diabetes Care 1993;16:828-34.

10. Kern PA. Lipid disorders in diabetes mellitus. Mt. Sinai J Med 1987;54:245-52.

11. Joslin's Diabetes mellitus, Fourteenth edition, Lippincott Williams and Wilkins 2005; chapter 33, pg. no. 563, 567, $568,569$.

12. Sharma PK and Poornima Chandak. Serum lipid profile in Diabetics with and without retinopathy. Indian Journal of Clinical Biochemistry. 1992;7(2):203-204.

13. Klein BE, Moss SE, Klein $\mathrm{R}$, et al. The Wisconsin epidemiologic study of diabetic retinopathy. Relationship of serum cholesterol to retinopathy and hard exudates. Ophthalmology 1991;98:1261-1265.

14. Van Leiden HA, Dekker JM, Moli AC, et al. Blood pressure, lipids and obesity are associated with retinopathy. The Hoorn Study. Diabetes Care 2002;25:1320-1325.

15. Haddad OA, Saad MK. Prevalence and risk factors for diabetic retinopathy among Omani diabetics. $\mathrm{Br}$ J Ophthalmol 1998;82:901-06.

16. Rema M, Pooniya M, Mohan V. Prevalence of retinopathy in non-insulin dependent diabetes mellitus at a diabetes centre in southern India. Diabetes Res Clin Pract 1996 Sept;34(1):29-36.

17. Lyons TJ, Jenkins AJ, Zheng D, et al. Diabetic retinopathy and serum lipoprotein subclasses in the DCCT/EDIC Cohort. Invest Ophthalmol Vis Sci 2004;45:910-918.

18. Larsson LI, Alm A, Lithner F, et al. The association of hyperlipidemia with retinopathy in diabetic patients aged 15-50 years in the county of Umea. Acta Ophthalmologica Scandinavica, 1999;77(5):585-591.

19. Hove MN, Kristensen JK, Lauritzen T, et al. The prevalence of retinopathy in an unselected population of type 2 diabetes patients from Arhus County, Denmark. Acta Ophthalmologica Scandinavica 2004;82(4):443-448.

20. Ozer PA, Unlu N, Demir MN, et al. Serum lipid profile in diabetic macular edema. Journal of Diabetes and its Complications, 2009;23(4):244-248.

21. Schonfeld G, Birge C, Miller JP, et al. Apolipoprotein B levels and altered lipoprotein composition in diabetes. Diabetes 1974; 23:827-834.

22. Taskinen MR. Lipoprotein lipase in diabetes. Diabetes Metab Rev 1987;3:551-570.

23. Freyberger H, Schifferdecker E, Schatz H. Regression of hard exudates in diabetic background retinopathy with etofibrate antilipemic agent. Med Klin 1994;89:594-597. 